\title{
The potential use of chickpeas in development of infant follow-on formula
}

\author{
Lovemore Nkhata Malunga', Shimrit Bar-El Dadon', Eli Zinal ${ }^{3}$, Zipi Berkovich', Shahal Abbo $^{2}$ and Ram Reifen ${ }^{1 *}$
}

\begin{abstract}
Background: Undernutrition during childhood is a common disorder in the developing countries, however most research has focussed much on its treatment rather than its prevention.

Objective: We investigated the potential of using chickpeas in infant follow-on formula production against the requirements of WHO/FAO on complementary foods and EU regulations on follow-on formula.

Methods: Chickpeas were germinated for 72 hours followed by boiling, drying and dehulling in order to minimise associated anti-nutrition factors. Saccharifying enzymes were used to hydrolyse starch to maltose and the resulting flours were analysed for their protein content and amino acid profile.

Results: The protein content (percentage) increased from $16.66 \pm 0.35$ and $20.24 \pm 0.50$ to $20.00 \pm 0.15$ and $21.98 \pm$ 0.80 for the processed desi and kabuli cultivar compared to raw chickpeas, respectively $(P<0.05)$. There was insignificant change $(P=0.05)$ in amino acid profile following processing and the resulting flour was found to meet the amino acid requirements of WHO/FAO protein reference for 0-24 month's children.

Conclusion: The designed chickpea based infant follow-on formula meets the WHO/FAO requirements on complementary foods and also the EU regulations on follow-on formula with minimal addition of oils, minerals and vitamins. It uses chickpea as a common source of carbohydrate and protein hence making it more economical and affordable for the developing countries without compromising the nutrition quality.
\end{abstract}

Keywords: Chickpea, Protein, Weaning formulae, Amino acid, Infant follow-on formulae

\section{Introduction}

Childhood malnutrition caused by the consumption of low nutrient density of weaning foods is common in the developing countries [1]. The growth rate among children of developing and developed countries is not significantly different during the first 4-6 months of life, a period characterised by breastfeeding $[2,3]$. However, the growth rate falters in children in developing countries immediately after the introduction of weaning foods which are usually of poor nutritional value [1-3]. Hence, nutritionally adequate and safe complementary feeding starting from the age of 6 months with continued breastfeeding up to 24 months of age or beyond is recommended by the World Health Organisation (WHO).

\footnotetext{
* Correspondence: ram.reifen@mail.huji.ac.il

${ }^{1}$ The School of Nutritional Sciences Plant Genetics, The Hebrew University of Jerusalem, P.O. Box 12, Rehovot 76100, Israel

Full list of author information is available at the end of the article
}

The use of novel follow on formulas, common in the developed world, to prevent early childhood malnutrition has not been tried in the developing world as research has focussed mainly on treatment rather than prevention [4]. The major concern to introduce infant follow on formula has been that of affordability and hygiene. Therefore, the introduction of a cost effective novel infants follow on (weaning) formula using simple, affordable, and sustainable technologies will likely improve the overall children nutrition in the developing countries.

Conventionally, infant follow on formulas in the developing world are exclusively made from either cow's milk protein or soy protein isolate blended with starch or corn syrup or dextrose, vegetable oil/fat and mineral and vitamin premixes [5]. In many developing countries, commercially available weaning foods are too expensive for the average family, so nursing mothers often depend on traditional weaning foods which often are low in 
nutritive value [6,7], and are characterized by low protein, low energy density and high bulk density. Cereals constitute the primary basis for most of the traditional weaning foods in Africa.

In this research, we investigated the use of processed chickpea for producing infant follow on formula without compromising the nutrition quality.

Chickpea was explored for this purpose because of its high nutrient composition and economic value. It is a good source of high quality protein, carbohydrates, vitamins (thiamine and niacin), minerals (calcium, phosphorous, iron, magnesium, and potassium) and its oil is rich with the essential fatty acid, linoleic [8,9]. Chickpea protein quality is similar to that of soy but with chickpea out scoring soy in seven of the ten essential amino acids in quantity.

Many attempts have been made to use chickpeas in non-dairy infant formulas [10-12] and in weaning food blends [13-15]. The protein efficiency ratio (PER), net protein retention (NPR) and net protein utilization (NPU) of chickpea based infant formula were not different to soy or milk based formula [10]. Similarly, when fed to malnourished children, there was no significant difference between chickpea based formula and commercial soy formula in the samples tested [11]. The mean percentage of absorption, retention and biological value of the chickpea formula were 72.4, 26.4 and 35.1 compared to that of soy $69.6,24.3$ and 34.0 , respectively.

However, the presence of anti-nutritional factors, such as oligosaccharides, trypsin inhibitors, phytic acid, tannin, and haemagglutinin has limited application of chickpea in food industry [16]. We recently reported that germinating chickpeas for 72 hours followed by boiling, drying and dehulling results in highest reduction in antinutritional factors with minimal nutrient loss [17]. We hypothesized that the resulting chickpea flour can be used for weaning food/infant follow-on formula production. The effect of cooking of germinated and dehulled chickpeas on protein content and its amino acid profile is yet to be fully evaluated.

Therefore, in an attempt to use chickpea in weaning food production, we investigated the effect of boiling, drying and dehulling on protein quantity and amino acid profile of germinated chickpea seeds. In addition, we designed, formulated, and determined the nutritional quality of chickpea-based infant follow on formula.

\section{Materials and methods} Materials

One kabuli cultivar of chickpea (Cicer arietinum L.), namely bar, was obtained from Volcani Center, Israelis Agricultural Research Institute and one desi cultivar of chickpea, namely ICC14088, was obtained from the Institute of Plant Sciences at the Hebrew University of
Jerusalem. All reagents were bought from Sigma-Aldrich Israel.

\section{Chickpea flour processing}

Chickpea grains were either (a) soaked, germinated, boiled dried and dehulled (GB) or (b) soaked, germinated, dried and dehulled (G) described by [17]. Briefly, Alcohol (70\% ethanol) disinfected chickpea samples were soaked in water in the ratio $1: 10(\mathrm{w} / \mathrm{v})$ for 12 hours and rinsed in water. The seeds were later placed in tray lined with absorbent paper and was later allowed to germinate at room temperature under dark environment. The seeds were rinsed with water at 12 hours interval and germination was terminated after 72 hours by freezing at $-20^{\circ} \mathrm{C}$ for 12 hours. Part of the germinated chickpea seeds were dried immediately after defrosting in a conventional air drier $\left(50^{\circ} \mathrm{C}\right)$ for 20 hours and labelled $(G)$. The remainder of the germinated chickpea seeds were placed in boiling water for 3 minutes after defrosting and rinsed 3 times in hot water in order to get rid of the foam before boiling them. Chickpeas were cooked in boiling water $\left(95-97^{\circ} \mathrm{C}\right)$ for 15 minutes and were immediately rinsed with hot water. The germinated chickpeas were dried in conventional air drier $\left(50^{\circ} \mathrm{C}\right)$ for 20 hours and labelled (GB). All seeds were manually dehulled before milling using a heavy duty blender (Model RM100, Duisburg, Germany) to pass through a 200 micrometres sieve.

\section{Rate of starch hydrolysis}

Chickpea flour was mixed with water $(9 \% \mathrm{w} / \mathrm{v})$ and heated at $90^{\circ} \mathrm{C}$ for 15 minutes. Temperature of the mixture was later reduced to $75^{\circ} \mathrm{C}$ and saccharifying amylase was added. The progress of starch hydrolysis was monitored by measuring the change in maltose and glucose concentration over time at 30 minutes interval until 120 minutes.

\section{Production of follow-on formulae}

After saccharification, corn oil, sucrose, carrageenan, vitamin premix, mineral premix and vanilla - banana flavour were added in amounts as described in Table 1. The mixture was blended at maximum speed for $3 \mathrm{mi}-$ nutes using a kitchen blender to liquefy.

Table 1 The proposed chickpea based infant follow-on formula formulation

\begin{tabular}{llll}
\hline Ingredient & Percent (\%) & Ingredient & Percent (\%) \\
\hline Chickpea flour & 8.26 & Vitamin premix & $9.95 \times 10-5$ \\
Oil (corn oil) & 2.44 & Mineral premix & $3.31 \times 10-5$ \\
Water & 87.58 & Carrageenan & 0.02 \\
Sucrose & 1.20 & Vannila or Banana flavor & 0.50 \\
\hline
\end{tabular}




\section{General methods}

Protein content was determined using AOAC (1990) method number 14.026 and amino acids were determined on HPLC using the procedure described by [8]. FAO/ WHO reference amino acid pattern for 6-36 months old children was used to calculate the essential amino acid score [18].

Disaccharides (sucrose and maltose) and glucose were determined by HPLC. Chickpea flour ( $3 \mathrm{~g}$ ) was mixed with $20 \mathrm{ml}$ of water $\left(85^{\circ} \mathrm{C}\right), 0.5 \mathrm{ml}$ carrez reagent 1 and $0.5 \mathrm{ml}$ carrez reagent 2 . The mixture was heated at $85^{\circ} \mathrm{C}$ for 20 minutes in a water bath after which it was allowed to cool down. Water was later added to make it to $25 \mathrm{ml}$ and centrifuged at $6000 \mathrm{rpm}$ for 7 minutes. The supernatants were filtered through a $0.45 \mu \mathrm{m}$ membrane paper and the filtrate was injected to HPLC. HPLC column $(6.5 \times 300 \mathrm{~mm}$, HPX-87P BIO-RAD $)$ was used at $80^{\circ} \mathrm{C}$, using HPLC grade water as a mobile phase at the flow rate of $0.5 \mathrm{ml} /$ minute and the injection volume of $40 \mu \mathrm{l}$. The running time was 18 minutes and detection temperature of $50^{\circ} \mathrm{C}$. Chickpeas sugar compounds were identified by comparing the retention times of respective standards.

\section{Statistical analysis}

Protein content analyses were conducted in triplicate and its data was analysed using one way analysis of variance on a JMP 07 statistical software (SAS Institute Inc., Cary, NC). Sample means were compared using Tukey HSD method and significant differences determined at $\mathrm{p}<0.05$.

\section{Results}

\section{Effect on protein content}

We used two chickpea cultivars (desi and kabuli) grown in Israel to determine the protein content. The results (Table 2) suggested that desi has less protein content compared to Kabuli in the studied cultivars. We determined the effect of (a) germination, and dehulling (G); (b) germination, cooking and dehulling (GB); (c) dehulling

\section{Table 2 The effect of processing on protein content}

\begin{tabular}{lll}
\hline Process & Protein (\%) \\
\cline { 2 - 3 } & Desi (ICCI4088) & Kabuli (Bar) \\
\hline Raw & $16.66 \pm 0.35^{\mathrm{b} 2}$ & $20.24 \pm 0.50^{\mathrm{b} 1}$ \\
Germinated, and dehulled (G) & $21.34 \pm 1.20^{\mathrm{a} 1}$ & $22.56 \pm 0.95^{\mathrm{a} 1}$ \\
Germinated, boiled and dehulled (GB) & $20.00 \pm 0.15^{\mathrm{a} 2}$ & $21.98 \pm 0.80^{\mathrm{a} 1}$ \\
Dehulled and boiled (DB) & $20.95 \pm 0.92^{\mathrm{a} 1}$ & $22.70 \pm 0.53^{\mathrm{a} 1}$ \\
Dehulled, soaked and boiled (DSB) & $21.36 \pm 0.85^{\mathrm{a} 1}$ & $22.78 \pm 0.50^{\mathrm{a} 1}$ \\
\hline
\end{tabular}

Data presented as means \pm standard deviation $(n=3)$.

Means in the same column with different letter superscripts are significantly different $(\mathrm{p}<0.05)$.

Means in the same row with the different number superscripts are significantly different $(p<0.05)$. and boiling; and dehulling, soaking and boiling on the protein content of chickpeas. The protein content increased higher in the desi cultivar (25\%) compared to Bar $(12 \%)$ in all process types suggesting that the increment was largely due to dehulling. Our results showed that after processing, the protein content was not significantly different between cultivars, suggesting that protein distribution in the cotyledon is uniform regardless of chickpea cultivar type.

\section{Effect on amino acid profile}

Amino acid profiles for G and GB chickpeas were compared. The result (Table 3) showed random but insignificant changes to the profile of amino acid following cooking. There were no changes in amino acids. The amino acid content in chickpeas was found to meet the amino acid profile of the WHO/FAO reference protein for $0.5-1$ and $1-2$ years children [18].

\section{Development of infant follow-on formula}

The starch component of the carbohydrate was hydrolyzed with saccharifying enzymes to maltose and other smaller sugars for easy digestion by infants. The level of sugars remained constant after 30 minutes suggesting that hydrolysis time should be 30 minutes (Table 4). The

Table 3 The amino acid profile of chickpeas flour after processing

\begin{tabular}{|c|c|c|c|c|}
\hline \multirow[t]{2}{*}{ Amino acid } & \multirow[t]{2}{*}{ G } & \multirow[t]{2}{*}{ GB } & \multicolumn{2}{|c|}{ FAO/WHO reference protein } \\
\hline & & & $(0.5-1 \mathrm{yr})$ & $(1-2 \mathrm{yr})$ \\
\hline Histidine & 2.42 & 2.51 & 2 & 1.8 \\
\hline Isoleucine & 4.16 & 4.03 & 3.2 & 3.1 \\
\hline Leucine & 7.59 & 7.35 & 6.6 & 6.3 \\
\hline Lysine & 6.04 & 6.10 & 5.7 & 5.7 \\
\hline Threonine & 4.78 & 4.30 & 3.1 & 2.7 \\
\hline Valine & 4.98 & 4.90 & 4.3 & 4.2 \\
\hline Total aromatic amino acid & 8.60 & 8.44 & 5.2 & 4.6 \\
\hline Total sulphur amino acids & 4.64 & 4.74 & 2.8 & 2.6 \\
\hline Alanine & 4.59 & 4.47 & & \\
\hline Aspartic acid & 13.34 & 13.24 & & \\
\hline Cystine & 2.61 & 2.83 & & \\
\hline Glutamic acid & 18.51 & 18.95 & & \\
\hline Glycine & 4.01 & 3.87 & & \\
\hline Proline & 4.35 & 4.79 & & \\
\hline Serine & 5.22 & 5.23 & & \\
\hline Tyrosine & 3.00 & 2.83 & & \\
\hline Methionine & 2.03 & 1.91 & & \\
\hline Phenylanine & 5.61 & 5.61 & & \\
\hline Arginine & 6.81 & 6.92 & & \\
\hline
\end{tabular}

Note: G stands for soaked, germinated, and dehulled and GB = soaked, germinated, boiled and dehulled. Kabuli cultivar (bar) was used. 
Table 4 Levels of sugars during hydrolysis of starch

\begin{tabular}{llllll}
\hline Time (minutes) & $\mathbf{0}$ & $\mathbf{3 0}$ & $\mathbf{6 0}$ & $\mathbf{9 0}$ & $\mathbf{1 2 0}$ \\
\hline Sucrose and maltose (\%) & 0.18 & 2.54 & 2.30 & 2.38 & 2.47 \\
Glucose (\%) & 0 & 0.94 & 0.90 & 0.68 & 0.90 \\
Total & 0.18 & 3.48 & 3.20 & 3.06 & 3.37 \\
\hline
\end{tabular}

results of sucrose and maltose have been reported together due to poor resolution between the two sugars. Our results suggest that at least $60 \%$ of the starch had been hydrolysed.

Finally, we adjusted the nutrient value of our developed product by fortification with minerals and vitamins for compliance with infant nutrition needs. The resulting formula is shown in Table 5 .

\section{Discussion}

In this study we explored the possibility of utilizing the whole chickpea grain for the production of infant follow-on formula without compromising nutritive value and quality. Currently, soy is used in both weaning and infant formulas. Chickpea protein quality is comparable to soy, however the cost of chickpea protein isolate would be much higher, as soy contains oil as a secondary high value product. The presence of antinutritional factors also limited its application in infant formulas.

We previously reported that germination for 72 hours followed by boiling, drying, and dehulling [GB] comparably

Table 5 Estimated nutrition value of the formulated product before fortification

\begin{tabular}{|c|c|c|c|c|}
\hline \multirow[b]{2}{*}{ Nutrient } & \multicolumn{2}{|c|}{$\begin{array}{l}\text { Chickpea based weaning } \\
\text { formula }\end{array}$} & \multicolumn{2}{|c|}{$\begin{array}{l}\text { Requirement per } \\
100 \mathrm{kcal}\end{array}$} \\
\hline & Per $100 \mathrm{ml}$ & Per $100 \mathrm{kcal}$ & Minimum & Maximum \\
\hline Calcium, mg & 14.70 & 23.48 & 50 & 140 \\
\hline Phosphorous, mg & 33.22 & 53.07 & 25 & 90 \\
\hline Magnesium, mg & 12.33 & 19.70 & 5 & 15 \\
\hline Manganese, mg & 0.18 & 0.28 & 0.001 & 0.1 \\
\hline Iron, mg & 0.39 & 0.62 & 0.6 & 2 \\
\hline Zinc, mg & 0.31 & 0.50 & 0.5 & 1.5 \\
\hline Potassium, mg & 23.63 & 37.74 & 60 & 160 \\
\hline Sodium, mg & 4.01 & 6.41 & 20 & 60 \\
\hline Copper, mg & 0.04 & 0.06 & 0.035 & 0.1 \\
\hline Protein, $g$ & 1.83 & 2.92 & 2.25 & 3.5 \\
\hline Sucrose, $g$ & 1.77 & 2.84 & & \\
\hline Carbohydrates, g & 4.87 & 7.7 & & \\
\hline Fat, $g$ & 3.00 & 4.80 & 4 & 6 \\
\hline $\begin{array}{l}\text { Total } \\
\text { carbohydrates, g }\end{array}$ & 6.64 & 10.61 & 9 & 14 \\
\hline Energy kcal & 62.59 & 100.00 & $60 / 100 \mathrm{ml}$ & $70 / 100 \mathrm{ml}$ \\
\hline
\end{tabular}

resulted in chickpea flour with less antinutritional factors content than all the other investigated processes in our research [17]. Chickpea protein content range between 18 to $24 \%$ and might increase to 24 or $28 \%$ after dehulling or germination, respectively [16,19-23]. Chickpeas have been shown to vary greatly in their nutrient distribution with cultivar [24-27]. The two broad categories of chickpea (desi or kabuli) were used in our study. First it was important to note that on average the protein content of chickpeas was not different after dehulling regardless of cultivar type meaning that any cultivar can be used. Second, boiling of germinated grains followed by dehulling does not affect negatively the amino acid profile of chickpea proteins.

Conventionally, novel infant follow on formulas are exclusively made from either cow's milk protein or soy protein isolate which is blended with starch or corn syrup or dextrose, vegetable oil/fat and mineral and vitamin premixes among other ingredients [5]. The ratio of protein and carbohydrate in chickpea proximate composition is 0.25 , which is similar to that of an infant follow-on formula formulation, suggesting that the whole chickpea grain can be utilized $[8,16]$. Therefore, we used chickpea as a common source for protein, carbohydrate and minerals with minimal supplementation of the later. The infant follow-on formula was formulated to meet the requirements stipulated in the codex standard on infant follow-on formula and EC directive $[28,29]$. The estimated nutrition value of developed chickpea based infant follow-on formula without fortification (Table 5) showed the need for calcium, sodium, and potassium supplementation to meet the requirements. Furthermore, we assumed loss of significant amount of water-soluble vitamins such that vitamin supplementation should meet the daily infant nutrition needs.

The process thereof is as follows; chickpea flour from process [GB] is mixed with boiling water. The mixture is kept at $90^{\circ} \mathrm{C}$ for 15 minutes and saccharifying enzymes are added after the temperature reduces to $75-80^{\circ} \mathrm{C}$ to hydrolyse starch for 30 minutes. The volume is adjusted to initial volume by adding water. Corn oil, sucrose, carrageenan, vitamin premix, mineral premix and flavour are added to the mixture which is later blended at maximum speed for 3 minutes. The product will later undergo UHT treatment and aseptically packed to ensure safety to children.

The developed product meets the minimum nutrition requirements of codex alimenterious and those of $\mathrm{EU}$ regulations. Also, literature indicates that chickpeas true protein digestibility, biological value, net protein utilization and protein efficiency ratio is higher than most legumes including soybean $[11,12,30,31]$. Since the whole chickpea is used, the cost of production is lower than 
existing formula products on the market. Therefore, the developed product does have the potential to be used in developing countries without compromising the nutrition quality. However, clinical trial might be needed to access the efficacy of the product.

The developed infant follow-on formula will not only benefit developing countries but also developed countries as an alternative to or replacement of soy based formulas. Unlike chickpea, soy contains phytoestrogens which have been reported to initiate estrogen receptormediated reactions as reviewed by [32,33]. Evidence from animal studies suggests that phytoestrogens have adverse effect on reproductive system even though not yet significantly correlated in human studies $[34,35]$. In human studies, ingestion of isoflavones rich diet by premenopausal women resulted in increased menstrual cycle [36]. In a retro respective cohort study done by Iowa University, it was found that women fed on soy based formula during infancy had a prolonged menstrual bleeding and felt greater discomfort with menstruation than those fed on cow's milk based formula [37]. A recent study in Israel with 694 infants aged between 324 months indicated that soy based formulas slow infantile breast tissue wearing [38]. Consequently, different governments have cautioned the general public from unnecessarily exposing infants to soy formula.

\section{Conclusion}

As shown in this study, chickpea can be used for infant weaning food/follow-on formula with minimal mineral and vitamin fortification. Germination for 72 hours followed by boiling, drying and dehulling increases the protein content but does not affect the amino acid profile of chickpeas. Similarly, we have shown that the difference in protein content of the seeds between cultivars is not important as final concentration of protein after processing does not vary with cultivar. The formulated chickpea based follow-on formula prior to micronutrient supplementation meets almost all the nutrient requirements of EC directive on infant follow-on formula except for calcium, sodium, and potassium.

This work will hopefully further encourage the introduction of chickpea based foods in places where this legume is part of the local staple food.

\section{Competing interests}

The authors declare that they have no competing interests.

\section{Authors' contributions}

LNM- participated in study design and writing the manuscript, and conducted the experiments. SBED- participated in experiments and drafting the manuscript. EZ- provided technical assistance. ZB - provided technical support. SA- plant geneticist. RR- head of group. All authors read and approved the final manuscript.

\section{Author details}

'The School of Nutritional Sciences Plant Genetics, The Hebrew University of Jerusalem, P.O. Box 12, Rehovot 76100, Israel. ${ }^{2}$ Plant Genetics The Hebrew University of Jerusalem, P.O. Box 12, Rehovot 76100, Israel. ${ }^{3}$ Tnuva Research and Development Center, Rehovot, Israel.

Received: 31 July 2013 Accepted: 8 January 2014

Published: 22 January 2014

\section{References}

1. Black RE, Allen LH, Bhutta ZA, Caulfield LE, de Onis M, Ezzati M, Mathers C, Rivera J, Study MCU: Maternal and child undernutrition 1 - maternal and child undernutrition: global and regional exposures and health consequences. Lancet 2008, 371:243-260.

2. Dewey KG, Peerson JM, Heinig MJ, Nommsen LA, Lonnerdal B, Deromana GL, Dekanashiro HC, Black RE, Brown KH: Growth-patterns of breast-fed infants in affluent (united-states) and poor (peru) communities implications for timing of complementary feeding. Am J Clin Nutr 1992, 56:1012-1018.

3. Mosha TC, Laswai HS, Dakiyo SOS: Breastfeeding, weaning practices and anthropometric status of children in Morogoro district, Tanzania. Ecol Food Nutr 1998, 37:309-338.

4. Bhutta ZA, Haider BA: Maternal micronutrient deficiencies in developing countries. Lancet 2008, 371:186-187.

5. Nasirpour A, Scher J, Desobry S: Baby foods: formulations and interactions (a review). Crit Rev Food Sci 2006, 46:665-681.

6. Okeiyi LC, Futiell MF: Evaluation of protein quality of formulation of sorghum grain flour. Nutr Rep Int 1983, 28:451-461.

7. Onofiok NO, Nnanyelugo DO: Weaning foods in West Africa: nutritional problems and possible solutions. Food Nutr Bull 1998, 19:27-33.

8. Zia-Ul-Haq M, Iqbal S, Ahmad S, Imran M, Niaz A, Bhanger MI: Nutritional and compositional study of desi chickpea (Cicer arietinum L.) cultivars grown in Punjab, Pakistan. Food Chem 2007, 105:1357-1363.

9. Milan-Carrillo J, Valdez-Alarcon C, Gutierrez-Dorado R, Cardenas-Valenzuela OG, Mora-Escobedo R, Garzon-Tiznado JA, Reyes-Moreno C: Nutritional properties of quality protein maize and chickpea extruded based weaning food. Plant Foods Hum Nutr 2007, 62:31-37.

10. Sotelo A, Hernandez M, Larracilla J, Arenas ML, Palapa E: Use of chik-pea (cicer-arietinum 6) in non-dairy formulas. 2. Nitrogen-balance in children with intolerance to lactose, fed with a formula based on chickpea and a commercial soy product. Arch Latinoam Nutr 1987, 37:468-479.

11. Sotelo A, Arenas ML, Hernandez M: Use of chickpea (cicer-arietinum-l) in non-dairy formulas.1. Chemical-composition and nutritive quality of chickpea and its comparison with commercial infant formulas. Arch Latinoam Nutr 1987, 37:551-559.

12. Ulloa JA, Valencia ME, Garcia ZH: Protein-concentrate from chickpea nutritive-value of a protein-concentrate from chickpea (cicer-arietinum) obtained by ultrafiltration and its potential use in an infant formula. J Food Sci 1988, 53:1396-1398.

13. Wondimu A, Malleshi NG: Development of weaning foods based on malted, popped, and roller-dried barley and chickpea. Food Nutr Bull 1996, 17:169-176.

14. Suhasini AW, Malleshi NG: Self-selection trials of wheat and chickpea based weaning foods on weanling rats. J Food Sci Technol 2003, 40:468-471

15. Gutierrez Dorado R, Cardenas Valenzuela OG, Alarcon Valdez C, Garzon Tiznado JA, Milan Carrillo J, Armienta Aldana E, Reyes Moreno C: Weaning food from quality protein maize and chickpea extruded flours. Interciencia 2008, 33:868-874.

16. El-Adawy TA: Nutritional composition and antinutritional factors of chickpeas (Cicer arietinum L.) undergoing different cooking methods and germination. Plant Foods Hum Nutr 2002, 57:83-97.

17. Malunga LN, Zinal E, Barel-Dadon S, Abbo S, Reifen R: Effect of combined germination, dehulling and boiling on mineral, sucrose, stachyose, fibrulose, and phytic acid content of different chickpea cultivars. AJFAND 2012, 12:6853-6867.

18. Joint FAO/WHO/UNU Expert Consultation, Geneva, Switzerland, 2002. In WHO Technical Report Series, Protein and Amino Acid Requirements in Human Nutrition, Report of a Joint WHO/FAO/UNU Expert Consultation. Geneva, Switzerland: World Health Organisation; 2007. 
19. Alajaji SA, El-Adawy TA: Nutritional composition of chickpea microwave cooking and other (Cicer arietinum L.) as affected by traditional cooking methods. J Food Compos Anal 2006, 19:806-812.

20. Attia RS, Shehata AME, Aman ME, Hamza MA: Effect of cooking and decortication on the physical-properties, the chemical-composition and the nutritive-value of chickpea (Cicer-Arietinum L). Food Chem 1994 50:125-131.

21. Rehman ZU, Shah WH: Thermal heat processing effects on antinutrients, protein and starch digestibility of food legumes. Food Chem 2005, 91:327-331.

22. Ghavidel RA, Prakash J: Effect of germination and dehulling on functional properties of legume flours. J Sci Food Agric 2006, 86:1189-1195.

23. Mansour EH: Biological and chemical evaluation of chick pea seed proteins as affected by germination, extraction and alpha-amylase treatment. Plant Foods Hum Nutr 1996, 49:271-282.

24. Khattak AB, Khattak GSS, Mahmood Z, Bibi N, Ihsanullah I: Study of selected quality and agronomic characteristics and their interrelationship in Kabuli-type chickpea genotypes (Cicer arietinum L.). Int J Food Sci Tech 2006, 41:1-5.

25. Gul MK, Egesel CO, Turhan $\mathrm{H}$ : The effects of planting time on fatty acids and tocopherols in chickpea. Eur Food Res Technol 2008, 226:517-522.

26. Nikolopoulou D, Grigorakis K, Stasini M, Alexis M, lliadis K: Effects of cultivation area and year on proximate composition and antinutrients in three different kabuli-type chickpea (Cicer arientinum) varieties. Eur Food Res Technol 2006, 223:737-741.

27. Rincon F, Martinez B, Ibanez MV: Proximate composition and antinutritive substances in chickpea (Cicer arietinum L) as affected by the biotype factor. J Sci Food Agric 1998, 78:382-388.

28. Codex Alimentarius Commission: Codex Standard for Follow-Up FormulaRome: 1989. Codex Stan 156-1987. Rome: Codex Alimentarius Commission; 1989.

29. European Commission. Commission Directive 2006/141/EC of 22 December 2006 on Infant Formulae and Follow-on Formulae and Amending Directive 1999/21/EC. In Directive 2006/141/EC. Brussels: Official Journal of the European Union: The Commission of the European Communities. Edited by Commission E. 2006.

30. Khan MA, Jacobsen I, Eggum BO: Nutritive-value of some improved varieties of legumes. J Sci Food Agric 1979, 30:395-400.

31. Liu LH, Hung TV, Bennett L: Extraction and characterization of chickpea (Cicer arietinum) albumin and globulin. J Food Sci 2008, 73:C299-C305.

32. Badger TM, Ronis MJJ, Hakkak R, Rowlands JC, Korourian S: The health consequences of early soy consumption. J Nutr 2002, 132:559s-565s

33. Chen AM, Rogan WJ: Isoflavones in soy infant formula: a review of evidence for endocrine and other activity in infants. Annu Rev Nutr 2004 24:33-54.

34. Bennetts HW, Underwood EJ, Shier FL: A specific breeding problem of sheep on subterranean clover pastures in Western Australia. Aust Vet $J$ 1946, 22:2-12.

35. Setchell KDR, Gosselin SJ, Welsh MB, Johnston JO, Balistreri WF, Kramer LW, Dresser BL, Tarr MJ: Dietary estrogens - a probable cause of infertility and liver-disease in captive cheetahs. Gastroenterology 1987, 93:225-233.

36. Cassidy A, Bingham S, Setchell KDR: Biological effects of a diet of soy protein-rich in isoflavones on the menstrual-cycle of premenopausal women. Am J Clin Nutr 1994, 60:333-340.

37. Strom BL, Schinnar R, Ziegler EE, Barnhart KT, Sammel MD, Macones GA, Stallings VA, Drulis JM, Nelson SE, Hanson SA: Exposure to soy-based formula in infancy and endocrinological and reproductive outcomes in young adulthood. J Am Med Assoc 2001, 286:807-814.

38. Zung A, Glaser T, Kerem Z, Zadik Z: Breast development in the first 2 years of life: an association with soy-based infant formulas. J Pediatr Gastroenterol Nutr 2008, 46:191-195.

doi:10.1186/1475-2891-13-8

Cite this article as: Malunga et al:: The potential use of chickpeas in development of infant follow-on formula. Nutrition Journal 2014 13:8.

\section{Submit your next manuscript to BioMed Central and take full advantage of:}

- Convenient online submission

- Thorough peer review

- No space constraints or color figure charges

- Immediate publication on acceptance

- Inclusion in PubMed, CAS, Scopus and Google Scholar

- Research which is freely available for redistribution 